\title{
THE ROLE OF REGIONAL ORGANISATIONS IN MANAGING ENVIRONMENTAL WATER IN THE MURRAY-DARLING BASIN, AUSTRALIA
}

\author{
by \\ A.M. ROBERTS, $*$ E.J. SEYMOUR,* AND D.J. PANNELL ${ }^{\$ *}$ \\ * Department of Primary Industries, Victoria. \\ $\dagger \quad$ Regional School of Business, La Trobe University. \\ $\$ \quad$ Future Farm Industries Cooperative Research Centre. \\ $\S \quad$ School of Agricultural and Resource Economics, University of Western Australia. \\ Acknowledgements: We appreciate the constructive comments provided by Alistair Watson, \\ Terry Hillman, Lin Crase, Gavan Dwyer and an anonymous reviewer.
}

Running title: Regional management of environmental water

\begin{abstract}
The benefits of local knowledge and engagement mean that regionally based catchment management organisations have the potential to make valuable contributions to environmental water management in the Murray-Darling Basin. Their capacity to contribute is assessed based on eight governance criteria. Their capacities are found to be highly variable across the criteria, with the main areas of weakness being clarity of roles, evidence-based decision making and data integration. Nevertheless, there would be benefits from involvement in several capacities: provision of local information for the asset prioritisation process, consultation with local stakeholders, and preliminary filtering of environmental assets prior to more detailed analysis for prioritisation. Modifications to institutional arrangements are needed, supported by new systems including training and support, systems to facilitate information flows between the different organisational levels, and a nationally-agreed process for initial filtering of environmental assets, consistent with Benefit-Cost Analysis principles.
\end{abstract}

Key words: decision-making, environment, Murray-Darling Basin, water

JEL codes: Q25, Q53, Q58, D02

\section{Introduction}

\subsection{Problems of the Murray-Darling Basin}

The Murray-Darling Basin (MDB) is a major supplier of Australia's agricultural production, provides water to over three million people and contains important 
environmental assets and ecosystems. It is under great stress from past water management decisions and, until recently, prolonged drought, and facing forecasts of adverse climate change (MDBA 2010a).

Management of the MDB involves multiple jurisdictions: the Australian Government, Victoria, New South Wales (NSW), South Australia (SA), Queensland and the Australian Capital Territory (ACT). A summary of the history of the reform process (MDBA 2010a) and lessons from past management and remaining challenges have been outlined by Young (2010a). Problems remain with over-allocation of water, failure to account for surface-groundwater connectivity and a lack of integrated management of environmental water. Despite positive reforms, including the establishment of water markets, there are major concerns about deteriorating environmental conditions in the Basin with 20 of the 23 major catchments being in poor to very poor condition (MDBA 2010a).

\subsection{Recent national reforms and the opportunity presented}

Recent reforms through the Commonwealth Water Act 2007 (hereafter called the Act) signal a more national approach to water regulation; objectives are outlined elsewhere (www.commlaw.gov.au/commlaw/legislation/ActCompilation1.nsf, accessed 23 February, 2011). Under the Act, the Murray-Darling Basin Authority (MDBA) has been established as an independent statutory authority and must prepare a Basin Plan for the integrated management of water resources. Responsibility for preparing the Basin Plan resides with the MDBA and responsibility for its adoption resides with the Commonwealth Water Minister (MDBA 2010a). Recent water reforms provide an important opportunity to protect key natural assets and ecosystems because when water buyback programs are completed, the EWH will be the largest single holder of entitlements in the MDB (Crase et al. 2010; Bennett 2010).

The Office of the Commonwealth Environmental Water Holder (CEWH) has been established under the Act to manage the Australian government's environmental water holdings. The CEWH is separate from the MDBA and its role is to protect and restore the environmental water assets of the MDB. Water held by the CEWH will be managed in accordance with the Environmental Watering Plan that is to be prepared by the MDBA in accordance with the Basin Plan (MDBA 2010a).

The Basin states have an advisory role in preparation of the Basin Plan but they have a major role in its implementation. Each Basin state has the authority and responsibility to manage the use of its water resources within the framework set by the Basin Plan. Environmental watering is managed by negotiation between state and local managers.

Whilst the relationship between the Commonwealth and Basin states has been articulated through the Act, there have been limited discussions about devolved decision-making, confined to the potential role of environmental trusts (Bennett, 2010; Young, 2010b). Given that the intent is for the MDBA to only perform tasks that cannot be undertaken more effectively at lower levels (MDBA 2010b), Catchment Management Organisations (CMOs) seem an obvious choice for local planning and management of environmental water. There are $18 \mathrm{CMOs}$ within the MDB, charged with planning and implementing projects to protect natural resources at the regional scale, in partnership with communities (Robins and Dovers 2007). 
Given the importance of striking a balance between a coordinated national approach and devolution to local institutions, the aims of this paper are: (1) to assess the capacity of CMOs (based on eight criteria) to contribute to environmental water management in the MDB; and (2) to identify roles and tasks to which CMOs can appropriately contribute, in order to achieve cost-effective outcomes from environmental water management.

\section{Methods}

\subsection{Assessing the capacity of CMOs to contribute to environmental water management in the $M D B$}

We undertook a desktop review of institutional arrangements for water for each Basin jurisdiction. Regional natural resource management (NRM) arrangements were summarised including the legislation providing the statutory setting for water management, current CMO roles in water management, water delivery arrangements and the role of other agencies and groups.

We reviewed two previous studies on Australian water institutions (Pagan 2009, Productivity Commission 2010) to identify governance criteria with which to assess the capacity of CMOs for a role in environmental water management. Eight criteria had been identified by the Productivity Commission (legitimacy, transparency, accountability, inclusiveness, fairness, integration, capability and adaptability) and five by Pagan (clear institutional objectives, interconnection with other formal and informal institutions, adaptiveness, appropriateness of scale and compliance capacity). Based on these studies we selected eight criteria to assess CMO performance (clear institutional objectives, transparency, accountability, interconnection with formal and informal institutions, adaptiveness, appropriateness of scale, integration and capability). Compliance capacity and fairness were omitted because of difficulty in assessing performance.

Fifteen studies in regional NRM were used as a basis for ranking CMO performance against the governance criteria. For each criterion, performance was rated 'high', 'moderate' or 'low'.

\subsection{Potential roles for CMOs in environmental water management}

Given the hydrological connectedness of environmental assets and ecosystems and the need for people affected by decisions made under the Basin Plan to understand their implications, the balance between centralised and devolved decision-making will receive increasing attention. We have identified several important roles to achieve outcomes from environmental watering.

One key role is to contribute information to the process of prioritising the allocation of water to different environmental assets. This could include identification of environmental assets, valuation of assets, assessment of the hydrological connectedness of assets to water resources, assessment of the type and severity of threatening processes affecting assets (water availability and other threatening processes), consideration of the feasibility of getting environmental water to priority assets, and assessment of local economic and social conditions influencing the 
acceptance and/or uptake of measures intended to improve environmental water management.

A second role is to consult with local stakeholders in the community. This can help provide information relevant to the valuation or management of assets, and to foster local acceptance of prioritisation decisions. The prioritisation process itself is a third role, and includes several component tasks. Management of environmental watering (setting of annual allocations for assets and within-year management) is a fourth key role. Finally, monitoring and adaptive management are needed. Based on our assessment and subject to meeting acceptable levels of governance, we considered the roles (high, moderate, minor or nil) that could be played by CMOs. We acknowledge that our analysis is relatively general and does not account well for institutional differences between the states. Nevertheless it provides a starting basis for considering an issue which has not previously received much attention.

\section{Results and discussion}

\subsection{Assessing the capacity of CMOs to contribute to environmental water management in the $M D B$}

Under current arrangements, although CMOs have a role in water management, states continue have the main responsibility, including for legislation [Table 1] and for water-delivery arrangements [Table 2]. Governance criteria are outlined [Table 3], along with evidence from previous studies and our assessment of CMO performance. We acknowledge that these assessments do not reflect the large variation between CMOs within jurisdictions, as has been reported previously (Seymour et al. 2008).

Insert Tables 1 and 2 near here

CMOs have roles of working in partnership with communities and of conducting projects to protect natural resources. Given that there are insufficient resources and that achievement of outcomes is difficult (Pannell and Roberts 2010), there can often be tensions between these roles. CMOs sometimes have to choose between actions that foster community involvement but provide minimal protection of natural resources, and actions that provide high resource protection but do not foster broad community involvement. This lack of institutional clarity is compounded by insufficient devolvement of power and autonomy to CMOs in all jurisdictions (Paton et al. 2004; Lockwood et al. 2009; Marshall 2008). Clarity of responsibility varies between states; CMOs in Victoria and SA have relevant statutory powers and those in NSW, Queensland and the ACT do not. Overall we suggest that a lack of clarity of institutional objectives for CMOs is a significant limitation to CMOs taking on leading roles in environmental water management [Table 3]. 
CMOs rank highly in accountability (reporting on budgets, activities and outputs), but low in transparency and integration. Other common challenges for CMOs include integration of data from multiple sources, use of published literature and formal decision making frameworks [Table 3]. Governments also find these areas difficult despite having greater resources, and the role for CMOs (or any other institution) needs to be considered in this light.

Because of their geographical locations and their sizes compared with state or national governments, CMOs are well placed to foster community inclusiveness and appropriate participation in environmental water management. Their performance (ranked moderate, Table 3) could be improved by including a wider range of community interests - many currently have a strong focus on agricultural interests (Lockwood et al. 2007; Broderick 2005). Due to their smaller scale (both in terms of geography and resources), CMOs are likely to be able to respond to local circumstances more quickly and with better local knowledge than larger organisations.

\subsection{Potential roles for CMOs in environmental watering}

There is a degree of tension between the ideal of devolving responsibility for decisions to the lowest possible level (Garrick et al. 2011) and the variable performance of CMOs [Table 3]. Nevertheless, if CMO performance is sufficient, or can be increased through training and support, there are a number of aspects of environmental water management to which CMOs could make valuable contributions [Table 4], particularly due to their access to local knowledge and perhaps lower transaction costs for engaging locally. Firstly, CMOs could contribute by providing local information to the prioritisation process. On many aspects of the process, CMOs are likely to have (or be able to obtain) local knowledge that is not available to state or national organisations (Roberts and Pannell 2009). For information about local economic and social conditions that are relevant to the decisions, CMOs may make a particularly valuable contribution. For asset identification, valuation, identification of threats and technical information, sound prioritisation would benefit from significant inputs from CMOs, although the primary responsibility lies with governments ${ }^{1}$.

\footnotetext{
${ }^{1}$ Here and later, when we refer to 'governments' and their responsibilities, this can potentially mean ministers, government departments or independent authorities such as the MDBA or CEWH.
} 
The second role listed in Table 4 is consultation with local stakeholders. This should be a particular strength of CMOs and in most cases would be better managed and implemented at the regional level, provided that CMOs are not required to promulgate unpopular messages to which they do not subscribe.

Thirdly, CMOs could contribute to the prioritisation process. In particular they could usefully conduct an initial screening of assets within their region, to reduce the number of environmental assets in contention for watering. This should be done using a consistent national process, developed by governments, with input from CMOs to ensure practicality. CMOs could also contribute by using local knowledge to check the information collated by state and national bodies for the prioritisation process. For the final selection of priority assets, responsibility should rest with governments. A process based on Benefit: Cost Analysis principles, such as the Investment Framework for Environmental Resources (INFFER, www.inffer.org), should be used (or adapted) for the final prioritisation. The prioritisation process needs to recognise and account for hydrological connectivity between assets; water provided to one asset may also benefit down-stream assets which may well be outside the CMO region.

CMOs with sufficient statutory responsibilities can make an important contribution to the management of environmental watering, particularly management of within-year water delivery. Responsibility for setting annual allocation priorities should rest primarily with governments, but CMOs have knowledge that should influence these decisions. Finally CMOs with statutory authority can make a moderate contribution to monitoring of environmental outcomes.

Implementation of these suggestions would require development of new institutional arrangements and systems in some jurisdictions and adaptation of systems in others. Structures and systems to facilitate information flows between the different organisational levels would be needed. Agreed processes for initial filtering of environmental assets would need to be developed at the national level. Finally, relevant capacity gaps in organisations would need to be addressed through training and support, both for CMOs and other organisations involved in the process.

\section{Conclusions}

Consistent with the principle of devolving responsibility to lowest possible level and subject to meeting acceptable levels of governance, CMOs could play an important role in delivering effective environmental water management in the MDB. Participating CMOs need to demonstrate a sufficient level of performance in governance criteria. Institutional clarity, transparency and integration are likely to present the largest challenges.

CMOs are well placed to provide local knowledge into the prioritisation process at relatively low transaction costs. They could provide information about which environmental assets should be considered for environmental watering, the values of 
those assets to the community, technical aspects of the assets, and local economic and social conditions. Consultation with local stakeholders could be efficiently led by CMOs, with results feeding into the prioritisation process. To reduce the requirement for detailed (and resource-intensive) evaluation of environmental watering options, CMOs could undertake a process of filtering the many environmental assets in contention down to a shorter list of good prospects. The responsibility for final prioritisation decisions should remain with governments. CMOs in Victoria and SA have stronger statutory powers for environmental water management than in other jurisdictions and are thus relatively more appropriate for taking on some of the roles discussed above.

There are several challenges in the current performance of CMOs. Some could be addressed by training and support, some by better resourcing, some by stronger guidelines from governments, and some by institutional changes to create incentives for a stronger focus on environmental outcomes.

Whatever the degree of involvement by CMOs (or other institution), the prioritisation process needs a strong basis in Benefit: Cost Analysis principles. These principles should guide the final prioritisation of environmental water management options, as well as guiding information requirements and other subsidiary processes.

\section{References}

Alexander, J.K., A.M. Roberts and D.J. Pannell (2010) "Victorian catchment management approaches to salinity investment", Australasian Journal of Environmental Management 17, pp. 45-52.

Auditor General (2008) Regional Delivery Model for the Natural Heritage Trust and the National Action Plan for Salinity and Water Quality (Canberra: Australian National Audit Office).

Bennett, J.R. (2010) "Making decisions about environmental water: an economics approach" Making Decisions About Environmental Water Allocations (Surry Hills, Australian Farm Institute) pp. 37-49.

Broderick, K. (2005) "Communities in catchments: implications for natural resource management", Geographical Research, 43(3), pp. 286-296.

Crase, L., B. Dollery and S.O'Keefe (2010) "Managing environmental water: lessons in crafting efficient governance structures", Economic papers (submitted)

Cullen, P. (2005) "Reflections on the First Decade of Regional Catchment Management and the Journey Ahead", Victorian Catchment Management Conference 2005 (Lakes Entrance, Victoria).

Farrelly, M. (2005) "Regionalisation of environmental management: a case study of the Natural Heritage Trust, South Australia", Geographical Research, 43(4), pp. 393-405.

Garrick, D., Lane-Miller, C. and McCoy, A.L. (2011). "Institutional innovations for governing environmental water in the western U.S." Economic papers (submitted)

Hamstead, M. (2010) Alignment of water planning and catchment planning (Canberra: National Water Commission).

Land and Water Australia (2006) Improving the NRM Knowledge System for Regions (Braddon: Land and Water Australia). 
Lane, M. B., and C.P. Robinson (2009) "Institutional complexity and environmental management: the challenge of integration and the promise of large-scale collaboration", Australasian Journal of Environmental Management, 16, pp. $16-24$.

Lockwood, M., J. Davidson, A. Curtis, R. Griffith and E. Stratford (2007) Strengths and Challenges of Regional NRM Governance: Interviews with Key Players and Insights from the Literature (Hobart: University of Tasmania).

Lockwood, M., J. Davidson, A. Curtis, E. Stratford and R. Griffith (2009) "Multilevel Environmental Governance: lessons from Australian natural resource management", Australian Geographer, 40(2), pp. 169-186.

Marshall, G. R. (2008) Community-Based, Regional Delivery of Natural Resource Management (Kingston: Rural Industries Research and Development Corporation).

Murray-Darling Basin Authority (MDBA) (2010a) Guide to the Proposed Basin Plan Volume 1: Overview (Canberra: MDBA). www.mdba.gov.au (accessed 11 February 2011)

Murray-Darling Basin Authority (MDBA) (2010b) Guide to the Proposed Basin Plan: Volume 2: Technical Background (Canberra: MDBA). www.mdba.gov.au (accessed 11 February 2011)

Northern and Yorke Natural Resources Management Board (2007) Natural Resources Management (NRM) Levy, Administration Fact Sheet No. 7.001 (Crystal Brook: Northern and Yorke Natural Resources Management Board, Government of South Australia).

Pagan, R. (2009). "Laws, customs and rules: identifying the characteristics of successful water institutions" Chapter 2. Reforming Institutions in Water Resource Management: Policy and Performance for Sustainable Development. (Earthscan, London) ISBN 978-1-84407-755-7. pp. 20-44.

Pagan, P., Crase, L. and Gandhi, V. (2009) "Institutional Constraints and Organizational Dynamics: The Case of Water Trade between the Australian Capital Territory and New South Wales" Chapter 4. Reforming Institutions in Water Resource Management: Policy and Performance for Sustainable Development. (Earthscan, London) ISBN 978-1-84407-755-7. pp. 62-80.

Pannell, D.J. and A.M. Roberts (2010) "The Australian National Action Plan for Salinity and Water Quality: a retrospective assessment" Australian Journal of Agricultural Resource Economics 54, pp. 437-456.

Pannell, D., A. Ridley, E. Seymour, S. Marsh and R. Wilkinson (2008) Capacity Building in Regional NRM: Issues in Prioritisation, Planning and Implementation of Environmental Works at the Regional Level (Kingston: Rural Industries Research and Development Corporation).

Paton, S., A. Curtis, G. McDonald and M. Woods (2004) Regional natural resource management: is it sustainable? Australasian Journal of Environmental Management, 11, pp. 259-267.

Productivity Commission (2010). Australia's urban water sector. Productivity Commission Issues Paper, September 2010. www.pc.gov.au (accessed 22 October 2010).

Queensland Competition Authority (2010) Annual Report 2009-10 (Brisbane: Queensland Competition Authority).

Roberts, A.M. and D.J. Pannell (2009) Piloting a systematic framework (SIF3) for public investment in regional natural resource management in dryland salinity in Australia. Land Use Policy 26,1001-1010. 
Robins, L., and S. Dovers (2007) "NRM regions in Australia: the 'haves' and 'have nots",, Geographical Research, 45(3), pp. 273-290.

Robinson, I., and B. Docker (2010) Managing Environmental Water for System-Wide Benefits (Surry Hills: Australian Farm Institute).

Ryan, S., K. Broderick, Y. Sneddon and K. Andrews (2010) Australia's NRM Governance System: Foundations and Principles for Meeting Future Challenges (Canberra: Australian Regional NRM Chairs).

Seymour, E., D.J. Pannell, A. Ridley, S. Marsh and R. Wilkinson (2008) "Decision making by catchment management organisations in Australia: current processes and capacity gaps", Australasian Journal of Environmental Management, 15, pp. 211-221.

South Australian Government (2010) Water For Good Annual Statement 2010 (Adelaide: Department for Water).

Young, M.D. (2010a) Environmental Effectiveness and Economic Efficiency of Water Use in Agriculture: the Experience of and Lessons from the Australian Water Reform Programme (Paris: Organisation for Economic Co-operation and Development), www.oecd.org/document/55/0,3343,en_2649_37465_44753399_1_1_1_1,00.h tml

Young, M. (2010b) "Managing environmental water". Making Decisions About Environmental Water Allocations (Surry Hills, Australian Farm Institute) pp. $51-60$. 
TABLE 1

SUMMARY OF INSTITUTIONAL ARRANGEMENTS FOR BASIN STATES WITHIN THE MURRAY-DARLING BASIN AUTHORITY

\begin{tabular}{|c|c|c|c|}
\hline & Regional NRM arrangements & $\begin{array}{l}\text { Key legislation relating to water } \\
\text { management }\end{array}$ & Role of regional bodies in water management \\
\hline $\begin{array}{l}\text { New South } \\
\text { Wales } 1\end{array}$ & $\begin{array}{l}\text { Catchment Management } \\
\text { Authorities (13 CMAs, } 8 \\
\text { located within MDB). } \\
\text { Statutory authorities. }\end{array}$ & $\begin{array}{l}\text { Water Management Act 2000; } \\
\text { Catchment Management Authorities } \\
\text { Act } 2003 \text {. }\end{array}$ & $\begin{array}{l}\text { Non-statutory role for environmental water. CMAs contribute to Env } \\
\text { Water Management Plans. Acts allow Minister to authorise CMAs to } \\
\text { manage environmental water, hold and deal in licences. CMAs have to } \\
\text { 'have regard' to Water Sharing Plans when developing catchment plans. }\end{array}$ \\
\hline Victoria $^{2}$ & $\begin{array}{l}\text { Catchment Management } \\
\text { Authorities (10 CMAs, } 5 \text { in } \\
\text { MDB). } \\
\text { Statutory authorities. }\end{array}$ & $\begin{array}{l}\text { Water Act 1989; Catchment and Land } \\
\text { Protection Act 1984; Water } \\
\text { Amendment (Vic Env Water Holder) } \\
\text { Act 2010; Water (Resources } \\
\text { Management) Act 2005; Env Protection } \\
\text { Act } 1970 \text { (SEPP); Heritage Rivers Act } \\
1992 .\end{array}$ & $\begin{array}{l}\text { CMAs have statutory powers for regional waterways, floodplain and } \\
\text { drainage ('bed and banks'). They have operational management of the } \\
\text { Environmental Water Reserve. CMAs are responsible for catchment } \\
\text { management planning involving river health. }\end{array}$ \\
\hline $\begin{array}{l}\text { South } \\
\text { Australia }^{3}\end{array}$ & $\begin{array}{l}\text { Regional NRM Boards }(8 \\
\text { NRM boards, } 1 \text { in MDB }) \text {. } \\
\text { Statutory authorities. }\end{array}$ & $\begin{array}{l}\text { South Australian Water Resources Act } \\
\text { 1997; Natural Resources Management } \\
\text { Act 2004; Waterworks Act 1932; } \\
\text { Environment Protection Act 1993. }\end{array}$ & $\begin{array}{l}\text { Statutory powers to: develop Water Allocation Plans; develop regional } \\
\text { water demand and supply plans; develop and implement regional NRM } \\
\text { plans including principles relating to 'water affecting activities'. SA } \\
\text { CMOs can supplement income through the collection of an NRM levy to } \\
\text { help fund water allocation planning and monitoring of water resources }\end{array}$ \\
\hline Queensland $^{4}$ & $\begin{array}{l}\text { Regional 'Committees', } \\
\text { 'groups' and 'associations' (14 } \\
\text { NRM bodies, } 3 \text { in MDB). } \\
\text { Non-statutory. }\end{array}$ & $\begin{array}{l}\text { Water Act } 2000 \text { (regional water } \\
\text { resource plans are subordinate } \\
\text { legislation); River Improvement Trust } \\
\text { Act 1940; Env Protection Act 1994; } \\
\text { Env Protection (Water Policy) } 1997 .\end{array}$ & $\begin{array}{l}\text { No statutory functions regarding water. Regional bodies develop NRM } \\
\text { plans, including for environmental water, in conjunction with the } \\
\text { community. Plan and deliver funding for on-ground works. }\end{array}$ \\
\hline $\begin{array}{l}\text { Australian } \\
\text { Capital } \\
\text { Territory }^{5}\end{array}$ & $\begin{array}{l}\text { ACT NRM Council. Non- } \\
\text { statutory advisory body hosted } \\
\text { within ACT Govt. }\end{array}$ & Water Resources Act 2007. & $\begin{array}{l}\text { No direct role in water management. Develop a Territory NRM Plan and } \\
\text { Investment Strategy in conjunction with the community. }\end{array}$ \\
\hline
\end{tabular}

${ }^{1} \mathrm{NSW}$ Office of Water http://www.water.nsw.gov.au (accessed 25 October 2010); Department of Environment, Climate Change and Water

http://www.environment.nsw.gov.au/environmentalwater/WaterManagementPlanning.htm (accessed 25 October 2010); Hamstead, M (2010). ${ }^{2}$ DSE (2009);

www.ourwater.vic.gov.au (accessed 22 October 2010); ${ }^{3}$ South Australian Government (2010), http://www.waterforgood.sa.gov.au (accessed 26 October 2010); South

Australian Water Corporation, http://www.audit.sa.gov.au/02-03/b/sawc.html; ${ }^{4}$ Department of Environment and Resource Management,

http://www.derm.qld.gov.au/water.html (accessed 3 November 2010); Queensland Competition Authority (2010); Queensland Government,

http://www.regionalnrm.qld.gov.au/ (accessed 3 November 2010); ${ }^{5}$ Robins \& Dovers (2007), ACT Natural Resource Management Council http://www.actnrmcouncil.org.au

(accessed 1 February 2011), Department of The Environment, Climate Change, Energy and Water http://www.environment.act.gov.au (accessed 1 February 2011). ${ }^{6}$ Northern and Yorke Natural Resources Management Board 2007. 
TABLE 2

WATER DELIVERY ARRANGEMENTS IN AUSTRALIAN STATES WITHIN THE MURRAY-DARLING BASIN (NOVEMBER 2010)

\begin{tabular}{|c|c|c|}
\hline & Water delivery arrangements & Key agencies and groups involved in water management \\
\hline $\begin{array}{l}\text { New South } \\
\text { Wales }^{1}\end{array}$ & $\begin{array}{l}\text { State Water Corporation delivers rural bulk water, delivers environmental flows, } \\
\text { manages infrastructure and has groundwater legislative responsibility. Local urban } \\
\text { water authorities deliver urban water. Irrigation water delivered by five irrigator- } \\
\text { owned corporations who are issued water management licences under Water } \\
\text { Management Act } 2000 \text {. }\end{array}$ & $\begin{array}{l}\text { NSW Office of Water, Department of Environment, Climate } \\
\text { Change and Water; Catchment Management Authorities; } \\
\text { Environmental Water Advisory Groups; State Water } \\
\text { Corporation; Local government. }\end{array}$ \\
\hline Victoria $^{2}$ & $\begin{array}{l}\text { Nineteen state-owned rural and urban water authorities (four urban and two rural in } \\
\text { MDB) manage and distribute water for human use and environmental water. Board } \\
\text { of each authority reports to Minister for Water. Rural authorities also have delegated } \\
\text { responsibility to develop, licence and manage groundwater. }\end{array}$ & $\begin{array}{l}\text { Department of Sustainability and Environment (Office of } \\
\text { Water); Catchment Management Authorities; Rural and urban } \\
\text { water authorities (state government); Local government. }\end{array}$ \\
\hline $\begin{array}{l}\text { South } \\
\text { Australia }^{3}\end{array}$ & $\begin{array}{l}\text { SA Water manages water infrastructure and delivers water based on managing a } \\
\text { number of water industry outsourcing contracts. It has groundwater legislative } \\
\text { responsibility. }\end{array}$ & $\begin{array}{l}\text { Department For Water; Office For Water Security; Regional } \\
\text { NRM Boards; Environment Protection Authority (EPA); SA } \\
\text { Water; local government. }\end{array}$ \\
\hline Queensland $^{4}$ & $\begin{array}{l}\text { The State has statutory responsibility for surface and groundwater, } 170 \text { service } \\
\text { providers manage water supply (statutory authorities, local government, companies } \\
\text { and water boards), registered under the Water Act } 2000 \text {. }\end{array}$ & $\begin{array}{l}\text { Department of Environment and Resource Management; } \\
\text { Queensland Water Commission; Water authorities; water } \\
\text { service providers. }\end{array}$ \\
\hline $\begin{array}{l}\text { Australian } \\
\text { Capital } \\
\text { Territory }^{5}\end{array}$ & $\begin{array}{l}\text { Department of the Environment, Climate Change, Energy and Water regulates and } \\
\text { monitors ACT water resources under the Water Resources Act } 2007 \text {. ACTEW own } \\
\text { the water assets and manage water delivery. The EPA determines annual allocations } \\
\text { when water is scarce. Trade is limited as water is mainly for urban consumption. }\end{array}$ & $\begin{array}{l}\text { Department of the Environment, Climate Change, Energy and } \\
\text { Water; Environment Protection Authority; ACTEW (territory- } \\
\text { owned water utility). }\end{array}$ \\
\hline
\end{tabular}

${ }^{1}$ NSW Office of Water http://www.water.nsw.gov.au (accessed 25 October 2010); Department of Environment, Climate Change and Water

http://www.environment.nsw.gov.au/environmentalwater/WaterManagementPlanning.htm (accessed 25 October 2010); ${ }^{2}$ DSE (2009); www.ourwater.vic.gov.au (accessed 22

October 2010); ${ }^{3}$ South Australian Government (2010), http://www.waterforgood.sa.gov.au (accessed 26 October 2010); South Australian Water Corporation,

http://www.audit.sa.gov.au/02-03/b/sawc.html; ${ }^{4}$ Department of Environment and Resource Management, http://www.derm.qld.gov.au/water.html (accessed 3 November

2010); Queensland Competition Authority (2010); Queensland Government, http://www.regionalnrm.qld.gov.au/ (accessed 3 November 2010); ${ }^{5}$ Department of the

Environment, Climate Change, Energy and Water http://www.environment.act.gov.au (accessed 1 February 2011). 
TABLE 3

CMO GOVERNANCE CRITERIA

\begin{tabular}{|c|c|c|}
\hline $\begin{array}{l}\text { Governance } \\
\text { criteria }\end{array}$ & Analysis of criteria & Performance \\
\hline $\begin{array}{l}\text { Clear } \\
\text { institutional } \\
\text { objectives }\end{array}$ & $\begin{array}{l}\text { As well as working in partnership with governments, a major CMO role is } \\
\text { to work in partnership with communities to plan and implement projects } \\
\text { to protect natural resources at the regional scale }{ }^{4} \text {. Relatively strong } \\
\text { statutory powers in Victorian and South Australia }{ }^{12} \text {, limited ones in NSW, } \\
\text { and no statutory powers in Queensland and ACT complicates clarity of } \\
\text { CMO roles with that of other institutions. CMOs want greater autonomy } \\
\text { and flexibility to enable them to conduct their roles }{ }^{1,2} \text { and have identified } \\
\text { that their roles and responsibilities need clarification }{ }^{4} \text {. }\end{array}$ & Low \\
\hline Transparency & 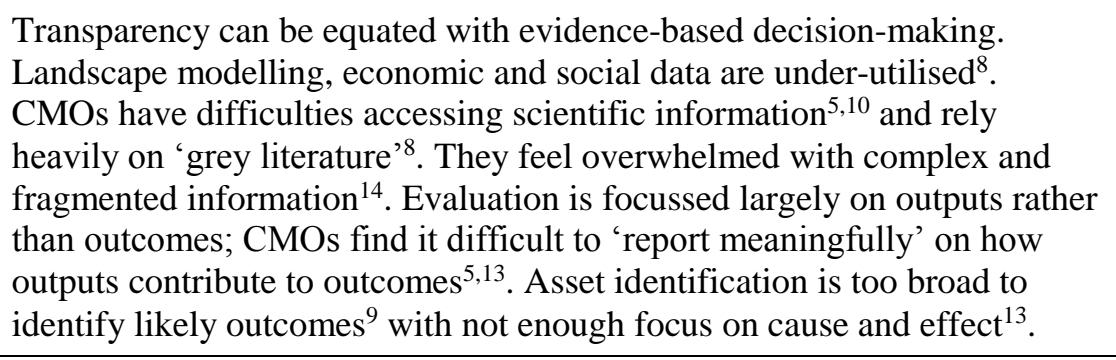 & Commonly low \\
\hline Accountability & $\begin{array}{l}\text { Upward accountability processes (reporting on budgets, activities, } \\
\text { outputs) are well established, to the point of being demanding and a large } \\
\text { transaction cost on } \mathrm{CMOs}^{2,6,10} \text {. Streamlining of reporting is needed }{ }^{2} \text {. }\end{array}$ & High \\
\hline $\begin{array}{l}\text { Interconnection } \\
\text {-formal and } \\
\text { informal } \\
\text { institutions }\end{array}$ & $\begin{array}{l}\text { Whilst CMOs have close connections with governments, the connection } \\
\text { with some sectors is not representative. Primary producers have greater } \\
\text { inclusion in CMO decision-making processes than other groups such as } \\
\text { urban residents and indigenous communities } \\
\text { good collaboration between CMOs and other agencies studies suggest } \\
\text { god. }\end{array}$ & Moderate \\
\hline Adaptiveness & $\begin{array}{l}\text { This is hard to assess from the literature, but the different institutional } \\
\text { structures operating in the Basin states for CMOs suggests that their } \\
\text { adaptive capacity is at least moderate. }\end{array}$ & Moderate \\
\hline $\begin{array}{l}\text { Appropriateness } \\
\text { of scale }\end{array}$ & $\begin{array}{l}\text { CMOs can have detailed local knowledge for environmental assets }{ }^{15} \text {. } \\
\text { CMOs in the MDB have good access to knowledge but have high } \\
\text { planning complexity due to cross-boundary issues }{ }^{4} \text {. Their scale is well } \\
\text { suited to management of natural resources at a regional/catchment scale, } \\
\text { but hydrological connectedness at larger scales is also required in } \\
\text { environmental watering. }\end{array}$ & Moderate \\
\hline Integration & $\begin{array}{l}\text { Capacity of CMOs for vertical and horizontal integration 'weak to } \\
\text { moderate' with 'patchy' integration of policy between governments } \\
\text { Cross-regional integration is a challenge for environmental issues } \\
\text { occurring at multiple scales }{ }^{11} \text {. CMOs generally do not use formal decision } \\
\text { frameworks to integrate different types of information }{ }^{8} \text {. }\end{array}$ & $\begin{array}{l}\text { Moderate } \\
\text { between } \\
\text { agencies } \\
\text { Low for data } \\
\text { integration }\end{array}$ \\
\hline Capability & $\begin{array}{l}\text { Capability varies greatly depending on size, resources and maturity, } \\
\text { having implications for establishment of effective systems }{ }^{2} \text {. In } 2008 \text {, only } \\
32 \% \text { of CMOs felt they had sufficient resources for achieving progress } \\
\text { against regional priorities }{ }^{5} \text {. Since that time, the resourcing of most CMOs } \\
\text { has declined. There are difficulties in attracting and retaining staff } 6 \text {. }\end{array}$ & $\begin{array}{l}\text { Highly variable, } \\
\text { ranges from low } \\
\text { to high }\end{array}$ \\
\hline
\end{tabular}

${ }^{1}$ Paton et al. (2004); ${ }^{2}$ Lockwood et al. (2009) ; ${ }^{3}$ Marshall (2008) $;{ }^{4}$ Robins \& Dovers (2007) $;{ }^{5}$ Auditor General (2008) ; ${ }^{6}$ Lockwood et al. (2007); ${ }^{7}$ Broderick (2005) ; ${ }^{8}$ Seymour et at. $(2008) ;{ }^{9}$ Alexander et al. $(2010) ;{ }^{10}$ Cullen $(2005) ;{ }^{11}$ Lane \& Robinson (2009) ; ${ }^{12}$ Farrelly (2005); ${ }^{13}$ Pannell et al. (2008); ${ }^{14}$ Land and Water Australia (2006); Roberts and Pannell $(2009)^{15}$. 
TABLE 4

POTENTIAL CONTRIBUTIONS OF CATCHMENT MANAGEMENT ORGANISATIONS TO ENVIRONMENTAL WATER MANAGEMENT

\begin{tabular}{|c|c|c|}
\hline Role & Component & Suggested CMO contribution \\
\hline \multirow{6}{*}{$\begin{array}{l}\text { Provide } \\
\text { information } \\
\text { for } \\
\text { prioritisation }\end{array}$} & Identification of assets & $\begin{array}{l}\text { Moderate. CMOs can have detailed local knowledge of } \\
\text { environmental assets within their boundaries, } \\
\text { sometimes more than governments. }\end{array}$ \\
\hline & Valuation of assets & $\begin{array}{l}\text { Moderate. Given their detailed local knowledge, } \\
\text { CMOs can contribute to valuation of assets, but } \\
\text { primary responsibility is with the Commonwealth } \\
\text { Environmental Water Holder. }\end{array}$ \\
\hline & $\begin{array}{l}\text { Hydrological } \\
\text { connectedness of assets }\end{array}$ & $\begin{array}{l}\text { Moderate. CMOs can have good understanding of the } \\
\text { hydrological connectedness of assets within their } \\
\text { region. Given the need for understanding hydrological } \\
\text { connectedness at Basin scale, CMO have at best a } \\
\text { moderate role, with primary responsibility resting with } \\
\text { governments. }\end{array}$ \\
\hline & Threatening processes & $\begin{array}{l}\text { Moderate. Given detailed local knowledge of } \\
\text { environmental assets and their role in delivery of } \\
\text { natural resource management programs, CMOs can } \\
\text { have good knowledge of the range of threatening } \\
\text { processes affecting environmental assets. }\end{array}$ \\
\hline & $\begin{array}{l}\text { Feasibility of delivering } \\
\text { environmental water }\end{array}$ & $\begin{array}{l}\text { High for CMOs already operating in this area } \\
\text { (Victoria, SA), likely to be low for NSW, Qld and the } \\
\text { ACT. }\end{array}$ \\
\hline & $\begin{array}{l}\text { Local economic and } \\
\text { social conditions }\end{array}$ & $\begin{array}{l}\text { High. Due to their size and connection to local } \\
\text { communities, CMOs could have a significant role. }\end{array}$ \\
\hline $\begin{array}{l}\text { Consult local } \\
\text { stakeholders }\end{array}$ & & High, due to strong connections to local communities. \\
\hline \multirow[t]{3}{*}{$\begin{array}{l}\text { Undertake } \\
\text { prioritisation }\end{array}$} & $\begin{array}{l}\text { Initial filtering of assets } \\
\text { using agreed process }\end{array}$ & $\begin{array}{l}\text { Moderate. CMOs can have detailed local knowledge of } \\
\text { environmental assets within their boundaries. }\end{array}$ \\
\hline & Checking information & Moderate. \\
\hline & $\begin{array}{l}\text { Overall state/national } \\
\text { prioritisation }\end{array}$ & Nil. Responsibility rests with governments. \\
\hline \multirow{2}{*}{$\begin{array}{l}\text { Management } \\
\text { of } \\
\text { environmental } \\
\text { water }\end{array}$} & $\begin{array}{l}\text { Setting of annual } \\
\text { allocation based on asset } \\
\text { priorities }\end{array}$ & $\begin{array}{l}\text { Low. Primary responsibility of setting priorities and } \\
\text { allocations rests with governments. }\end{array}$ \\
\hline & Within-year management & $\begin{array}{l}\text { High for Victoria and South Australia due to having } \\
\text { statutory responsibility, low for NSW, Qld and ACT. }\end{array}$ \\
\hline $\begin{array}{l}\text { Monitoring of } \\
\text { environmental } \\
\text { outcomes }\end{array}$ & & $\begin{array}{l}\text { Moderate for Victoria and South Australia and nil or } \\
\text { low for NSW. Qld and ACT, but primary } \\
\text { responsibility lies with the Environmental Water } \\
\text { Holder. }\end{array}$ \\
\hline
\end{tabular}

